\title{
A Case with Laron Syndrome
}

\author{
(i) İlker Tolga ÖZGEN11, id Esra KUTLU1', id Yaşar CESUR¹, id Gözde YEŞiL²
}

1Bezmialem Vakıf University Faculty of Medicine, Department of Pediatric Endocrinology, İstanbul, Turkey

2Bezmialem Vakıf University Faculty of Medicine, Department of Medical Genetics, İstanbul, Turkey

\section{ABSTRACT}

Laron syndrome (LS) is a rare disorder leading to short stature as a result of growth hormone (GH) insensitivity. It is caused by mutations in $\mathrm{GH}$ receptor gene and characterized by post-natal growth retardation, craniofacial abnormalities, high serum GH and low insulin-like growth factor-I (IGF-I) levels. Several different genetic mutations have been documented up to date. In this article, a patient with LS is reported.

A 2-year-old female patient was admitted to the hospital with the complaint of short stature. Her height and weight was $71.7 \mathrm{~cm}[<3 \mathrm{p} .,-4.09$ standard deviations (SDS)] and $9.7 \mathrm{~kg}(<3$ p., -2.2 SDS) respectively. She had dysmorphic features such as maxillary hypoplasia, blue sclera, small hands and feet, and extreme proportionate shortness. She had a high basal serum GH level $(61.879 \mathrm{ng} / \mathrm{mL})$, whereas serum IGF-I $(<10$ $\mathrm{ng} / \mathrm{mL})$ and IGF-binding protein $3(<0.54 \mathrm{ng} / \mathrm{mL})$ concentrations were significantly low. Both clinical and laboratory measurements were consistent with LS. A missense variation leading to a stop codon (W182X) was determined in GH receptor gene. Recombinant IGF-I therapy improved height z-score from -4.09 to -3.4 SDS after 24-month treatment.

In this report, we presented a case with LS. The description of a mutation in a specific region may be helpful in defining the genetic pattern of other patients with LS and in determining whether it is a mutation with a founder effect that is unique in the Turkish population.

Keywords: Growth hormone insensitivity, Laron syndrome, insulin-like growth factor-I therapy, short stature

\section{Introduction}

Along with autosomal recessive inheritance, the Laron syndrome (LS) is a congenital disorder, which is infrequent in prevalence. The disease was firstly diagnosed by Laron et al. (1) on several oriental Jewish families in 1966. Clinically, post-natal growth retardation is observed in patients with this syndrome. Adult length of these patients remain between -4 and -10 SDS unless they receive necessary treatment (2).

Growth hormone $(\mathrm{GH})$ insensitivity occurs in these patients as a result of $G H$ receptor (GHR) gene defects. Appropriate insulin-like growth factor-I (IGF-I) secretion in response to endogenous and exogenous $\mathrm{GH}$ does not occur and serum IGF-I value remains low while serum GH value is high. To date, around 99 mutations have been documented in GHR gene (chromosome 5p13-p12) in more than 300 cases (3).

In this article, a patient who had a mutation in her GHR gene and who received mecasermin (IGF-1) treatment for 24 months is reported.

\section{Case Report}

Two-year old female patient was admitted to the hospital with the complaint of short stature. She had a height of $71.7 \mathrm{~cm}(<3 \mathrm{p}$., -4.09 SDS) and a weight of $9.7 \mathrm{~kg}(<3$ p., -2.26 SDS). Her birth weight, length and head circumference were $3420 \mathrm{gr}(50-75$ p.), $47 \mathrm{~cm}(10-25$ p.) and $41 \mathrm{~cm}(50-75$ p.) respectively. Her parents were third-degree relatives. The height of the father and mother

Address for Correspondence: ilker Tolga ÖZGEN, Bezmialem Vakıf University Faculty of Medicine, Department of Pediatric Endocrinology, İstanbul, Turkey 
were $167 \mathrm{~cm}$ (3-10 p., 1.38 SDS) and $155 \mathrm{~cm}$ (10 p., -1.3 SDS) respectively. She had a healthy sibling. In her physical examination, a hypoplastic nasal bridge, frontal bossing, small mandible, blue sclera, small hands and feet, and small extremities were observed (Picture 1). Neurological development was suitable with her age. Abdominal ultrasonography, cardiac evaluation and her cranial magnetic resonance imaging were also normal.

Complete blood count and renal and liver function tests, fasting blood glucose, serum electrolytes, blood $\mathrm{pH}$, thyroid function tests were normal. In accordance with X-ray of wrist, the bone age of the case was the same as a newborn. She had high basal serum GH levels $(61.879 \mathrm{ng} / \mathrm{mL})$, low serum IGF-I $(<10 \mathrm{ng} / \mathrm{mL}$; normal range for age, $16-143 \mathrm{ng} / \mathrm{mL}$ ) and low insulin-like growth

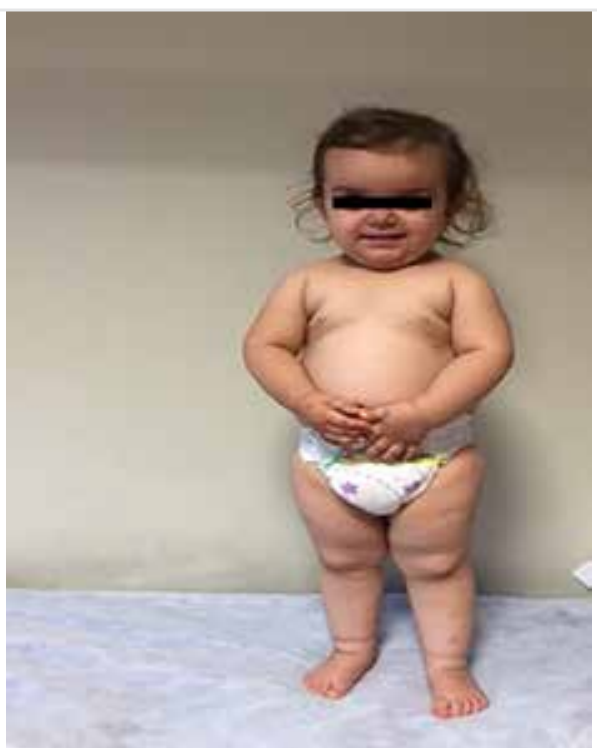

Picture 1. Patient at the beginning of the therapy (two years old)

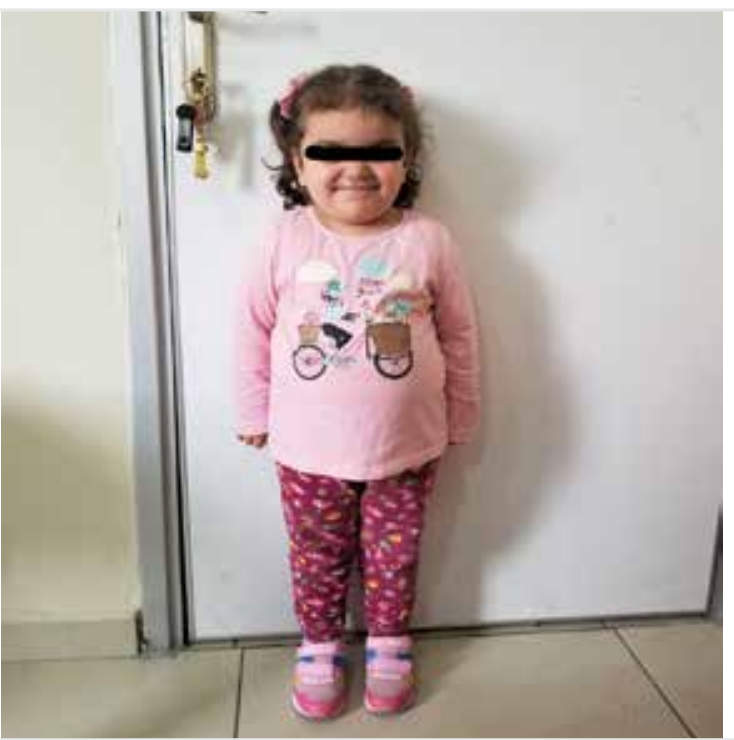

Picture 2. Patient at the $24^{\text {th }}$ month of therapy (four years old) factor binding proteins $-3(<0.54 \mathrm{ng} / \mathrm{mL}$; normal range, $0.8-3.9$ $\mathrm{ng} / \mathrm{ml}$ ). The IGF-I (somatomedin) generation test was performed with a dose of $0.1 \mathrm{mg} / \mathrm{kg} /$ day for four days. However, IGF-I value of the patient remained below $0.25 \mathrm{ng} / \mathrm{mL}$ after GH. Hereby, her clinic presentation and laboratory values were consistent with LS. In her genetic examination, homozygote W182X variation was detected in her GHR gene. Moreover, her parents, both her mother and father, were heterozygotes carrier for the same variation. (The variation was predicted to be pathogenic according to 3 modelling programs (scale-invariant feature transform, Polyphen 2, Muationtaster). Mecasermin (IGF-I) treatment with the dose of $0.12 \mathrm{mg} / \mathrm{kg}$ twice a day by subcutaneous injection was initiated to the case. At the end of 24 months, with IGF-I therapy, the height and height z-scores of the patient were improved from 71.7 $\mathrm{cm}$ to $85.1 \mathrm{~cm}$ and from -4.09 to -3.4 , respectively, whereas her body mass index (BMI) z- score increased from 1.51 to 2.92 . Her anthropometric development was given in Table 1.

\section{Discussion}

Our patient was a typical case of LS with a classical GH insensitivity syndrome (GHIS) phenotype and laboratory findings. Normally, patients with LS have a standard birth weight and length (4). Over time, short stature and obesity become evident. In the early stage, mild mental retardation, craniofacial anomalies (such as facial bone growth is particularly retarded and they exhibit frontal bossing and a saddle nose), blue sclera, defective and crowded teeth, sparse hair growth, small gonads and genitalia, small hands and feet (acrohypoplasia), obesity, retarded skeletal maturation, delayed puberty, and hypoglycemia can be observed. In the late stage, patients show very short stature ( -4 to -10 height SDS), marked progressive obesity, muscle underdevelopment and weakness, osteoporosis, hypercholesterolemia, hyperinsulinemia, and various degrees of glucose intolerance (5-7). When the intellectual development of these patients is taken into consideration, it seems

Table 1. Anthropometric measure according to years

\begin{tabular}{|c|c|c|c|}
\hline & $\begin{array}{l}\text { At the } \\
\text { beginning of } \\
\text { therapy }\end{array}$ & $\begin{array}{l}\text { At the } 13^{\text {rd }} \\
\text { month of } \\
\text { therapy }\end{array}$ & $\begin{array}{l}\text { At the } 24^{\text {th }} \\
\text { Month of } \\
\text { therapy }\end{array}$ \\
\hline Age & 2 years old & $\begin{array}{l}3 \text { years and } \\
1 \text { month old }\end{array}$ & 4 years old \\
\hline Height (cm) & 71.7 & 80.9 & 85.1 \\
\hline Height z-score & -4.09 & -3.5 & -3.4 \\
\hline Weight & 9.7 & 13 & 16 \\
\hline Weight z-score & -2.2 & -0.6 & -0.39 \\
\hline BMI* & 18.8 & 19.9 & 22.09 \\
\hline BMI z-score & 1.51 & 2.38 & 2.92 \\
\hline
\end{tabular}


to vary in a wide range from normal intelligence to severe mental retardation in accordance with their psychological examination (5).

LS has one effective treatment: rIGF-I is administered on daily basis starting from early childhood and throughout whole life of the patient. Although these patients may not reach standard adult height, they can experience considerable increase in their height with the treatment when compared to the cases who do not receive the treatment (8). Previous data have demonstrated a good increment of growth rate during the first year of treatment. Growth velocity was $5.6 \mathrm{~cm} /$ year in the Ecuadorian study (9), and $4.3 \mathrm{~cm} /$ year in the European and North America studies (10) compared to baseline. Although, these three studies used the same amount of rhIGFI, with twice daily administrations, growth response to treatment was not similar. Many factors may affect growth response to treatment such as age of children or poor compliance to therapy. Moreover, it can be speculated that genotype may also affect growth response. However as the disease is rare, it is not possible to perform large studies about relationship between genotype and treatment response. So, the case reports including treatment results and genotypes may also serve to product meta-analysis on the issue about relationship between genotype and response to mecasermin treatment. The growth velocity of our patient was $8.49 \mathrm{~cm} /$ year with a 13 -month treatment. However, in the second year of treatment her growth velocity was only $4.58 \mathrm{~cm} /$ year. The cases with LS, particularly when they are infant, can experience hypoglycemia, which is the most prevalent side effect, prior to or in the process of the therapy (2). However; no hypoglycemia is detected during the treatment process of our case. On the other hand, the BMI z-score increased rapidly. Obesity, another common symptom, is considered to be a compensatory mechanism aiming normalization of hypoglycemia (sex hormones, glucocorticoids, among others)

The main pathogenetic defect is in GH-IGF axis in which IGF-I is not synthesized due to the insensitivity of $\mathrm{GH}$ receptor. The GHR gene on the short arm of chromosome 5 includes 9 exons comprising 638 amino acid residues in its mature form. The mature GH receptor is consisted of an extracellular domain (encoded by exons 3-7), a single transmembrane domain (encoded by exon 8) and a cytoplasmic domain (encoded by exons 9 and 10) (1). GHR mutations are mainly detected in extracellular domain (3). The phenotype-genotype relationship in GHIS is widely variable. The same GHR mutation may be associated with a wide variation of phenotype. Although, severe phenotype is observed in homozygous cases, no clinical finding may be present in heterozygous individuals except compound heterozygous patients. Blanco et al. (11) described a homozygous non-sense mutation (with a potential lack of GHR protein) leading to a very severe LS phenotype (height from -5.4 to -7.04 SD) with their parents having a nearly normal phenotype. Similarly in our case, although the parents of patients with LS had heterozygous W182X alleles and normal phenotype, the patient had homozygous mutation.

\section{Conclusion}

A child with LS with a homozygous GHR W182X mutation is presented. The description of a mutation in a specific region may be helpful in defining the genetic pattern of other patients with LS and in determining whether it is a mutation with a founder effect that is unique in the Turkish population. Furthermore as the disease is rare, the case reports including treatment results may also serve to product meta-analysis on the issue about relationship between genotype and response to mecasermin treatment.

\section{Ethics}

Informed Consent: A consent form was completed by all participants.

Peer-review: Externally peer-reviewed.

\section{Authorship Contributions}

Concept: İ.T.Ö., E.K., G.Y., Design: İ.T.Ö., Y.C., G.Y., Data Collection or Processing: İ.T.Ö., E.K., G.Y., Analysis or Interpretation: İ.T.Ö., E.K., Y.C., Literature Search: İ.T.Ö., E.K., Writing: İ.T.Ö., E.K.

Conflict of Interest: No conflict of interest was declared by the authors.

Financial Disclosure: The authors declared that this study received no financial support.

\section{References}

1. Laron Z, Pertzelan A, Mannheimer S. Genetic pituitary dwarfism with high serum concentration of growth hormone-a new inborn error of metabolism? Isr J Med Sci 1966;2:152-5.

2. Laron Z, Lilos P, Klinger B: Growth curves for Laron syndrome. Arch Dis Child 1993;68:768-70.

3. David A, Hwa V, Metherell LA, Netchine I, Camacho-Hubner C, Clark AJ et al. Evidence for a continuum of genetic, phenotypic, and biochemical abnormalities in children with growth hormone insensitivity. Endocr Rev 2011;32:472-97.

4. Laron Z, Lilos P, Klinger B. Growth curves for Laron syndrome. Arch Dis Child 1993;68:768-70.

5. Laron Z, Laron syndrome (primary growth hormone resistance or insensitivity): the personal experience 1958-2003. J Clin Endocrinol Metab 2004;89:1031-44.

6. Rosenbloom AL, Guevara Aguirre J, Rosenfeld RG, Fiedler PJ. The little women of Loja-- growth hormone-receptor deficiency in an inbred population of southern Ecuador. $\mathrm{N}$ Engl J Med 1990;323:1367-74.

7. Ayling RM, Ross R, Towner P, Von Laue S, Finidori J, Moutoussamy $S$ et al. A dominant-negative mutation of the growth hormone receptor causes familial short stature. Nat Genet 1997;16:13-4.

8. Chernausek SD, Backeljauw PF, Frane J, Kuntze J, Underwood LE, GH Insensitivity Syndrome Collaborative Group: Long-term treatment with recombinant insulin-like growth factor (IGF)-I 
in children with severe IGF-I deficiency due to growth hormone insensitivity. J Clin Endocrinol Metab 2007;3:902-10.

9. Guevara-Aguirre J, Rosenbloom AL, Vasconez O, Martinez V, Gargosky SE, Allen L et al. Two-year treatment of growth hormone (GH) receptor deficiency with recombinant insulin-like growth factor I in 22 children: comparison of two dosage levels and to GH-treated GH deficiency. J Clin Endocrinol Metab 1997;82:629-33.

10. Ranke MB, Savage MO, Chatelain PG, Preece MA, Rosenfeld RG, Wilton P. Long-term treatment of growth hormone insensitivity syndrome with IGF-I. Results of the European Multicentre Study. The Working Group on Growth Hormone Insensitivity Syndromes. Horm Res 1999;51:128-34.

11. Gorbenko del Blanco D, de Graaff LC, Visser TJ, Hokken-Koelega AC. Growth hormone insensivity syndrome caused by a heterozygous GHR mutation: Phenotypic variability owing to moderation by nonsense-mediated decay. Clin Endocrinol (Oxf) 2012 May;76:70612. 